值に対して大体一定となつた $\omega_{\mathrm{c}}$ の储 $\omega_{c 2}$ との比を求めると 次に示主如く大体 0.97 附近の佰となる。

以上の事害は振子型動吸振器設計上の大体の指針文示守も のであり、この方法に依て大凡の調整空行つた上、少出来上
つたものに就て奏驗的に精細な調整を行へばそのクランク軸

に適合した完全な動吸拨器が得られるであらう。

(昭利 16 年 6 月 24 日受付)

\title{
クランク軸に應用した動吸振器
}

(第 4 報、波動型動吸振器に関する実驗)

(昭和 12 年 4 月 4 日 第 14 期走持総命講演會、昭和 12 年 11 月 13 日 隹用力学潇演會、昭和)

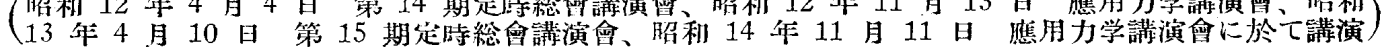

王 員 谷 $下$ 市 松 ${ }^{(2)}$

摘 要

第 1 報及び第 2 報に於て動吸振器の特性及び发焦用法の理論を考究し、第 3 報に於てばね型及び振一型振動器に 関する実驗結果を報告したが、本報に於ては彈性軸の豩り搬動を波動型動吸张器に依て吸收する実驗の結果を遮 ベる。

16. 波動型動吸振器に関する実驗

1. 予備実驗液体波動る゙動吸振器として伐用し得るこ とは容易に想像し得ることであるが、先づ簡單な実驗を行つ てこれる確かめる必要を感じ、回轉しない場合、即ち重力の 作用の下における波動に関して子備実驗を行つた。

予備実驗の第1として種々な る形狀 (矩形、円形、三角形) の 容器內の液体の定常波の自然振 動数を測定した。特別な形狀の 容器に対しては自然振動数の理 論式が求められてるるが、その 様な容器に対しては理論式を確 かめ、文理論式の知られてるな いものに対しては実驗的に求め て見たのである。この場合に使 用した実驗装置を第 85 図に示 す。実驗せんとする容器 $A$ に

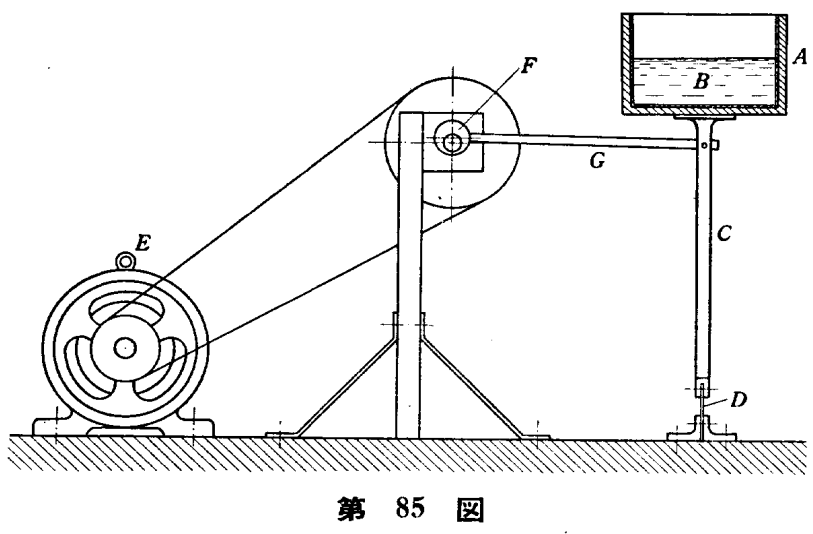

液体波動の自然振動数に一致するとき波動は共鳴してその振 幅は甚だ大きくなっ。故に電動機の速度を徐々に変化して液 体波動の共鳴する所を探せば、このときの振動数が波の自然 振動数に等しい。斯くして得られた結果は、第 86 図乃至第 89 四に示す如くである。售容器つ厚さは自然振動数には無 関係であるが、この場合には常に $7.5 \mathrm{~cm}$ とした。

第 86 図乃至第 88 図は第 85 A 図に示吉如き矩形断面の容器の 場合で第 86 図は長さ $\ell$ の種 々なる值に対する深さ $h$ と自 然振動数との関倸を示し、第 87 図は $h=5 \mathrm{~cm}$ に対する長さの 逆数 $1 / l$ と自然振動数との関係 を示し、第 88 図付 $l=16 \mathrm{~cm}$, $h=2 \mathrm{~cm}$ ○容器に対方波長の 逆数 $1 / \lambda$ 自然振動数との関 係を示す。これ等の図における 曲線は、矩形容器內の波動の每 分振動数 $N$ に対古る理論式(3)

$$
N=\frac{60}{2 \pi} \sqrt{\frac{n \pi g}{l} \tanh \frac{n \pi h}{l}}
$$

を線図に画いたものである。但し $n$ は波の次数を表はす定数 で、丁度波形の節点の数に相等しい。 $n=2,4,6, \ldots \ldots$ に相 當する所謂対称波は如上の方法では発生もしないし、文動吸 振器としては役立たないのである。動吸振器の目的に対して は非対称的な $n=1,3,5, \ldots \ldots$ に相當古る波動のみが必要 である。第 88 困は水銀を用ひた結果であり、その他の図は 何れも水を使用した結果である。自然振動数は液の種類には 関係しないが、併し水の場合に明瞭に現はれる波は 1 次と 3 次位で 5 次以上の高次波は不明膫であつたが、水銀の場合

(3) H. Lamb, Hydrodynamics, 6th ed. (1932), p. 3666.

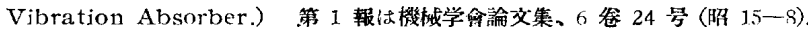

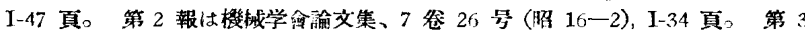

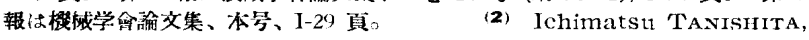
Nember. Tokyo Imperial University. 東京䎡国大学。

第 7 卷第 28 号 (第 1 部)] 
に江 $n=11$ 或は乞れ以上迄明膫に現はれた。佾波長を入 と市礼ば $l=n \lambda / 2$ なっ関係があるから、 $1 / \lambda=n / 2 I$ とな 另。第 86 四に於て $n=1$ 及び $l$ の大なる值の場合には 大体実驗估は理满式之合致してるるが、 $n=3$ 及び $l$ の值 が小さくなると実䮲值は理論曲線より少しく離れてるる。 これは侑心輪の偏心距離が $0.5 \mathrm{~mm}$ の場合であるが、それ が $2 \mathrm{~mm}$ の埸合には唡者の喰違ひが更に積だしく現はれ た。故にこの朎溒ひは偏心卯離の大なっために現はれるる のであり、徉て上記の理論式は正しいものと考へられる。

第 89 四は间図に記入した如き底角 $90^{\circ}$ ○逆三角形断 面の容器に対安を結果を示し、直線仙同容器內の波動の每 分振動数に対士口理論式(4)

$$
\begin{aligned}
& N_{n=1}=\frac{60}{2 \pi} \sqrt{\frac{g}{h}} \\
& N_{n=3}=\frac{60}{2 \pi} \sqrt{3 \cdot 92 \frac{g}{h}} \fallingdotseq 2 \frac{60}{2 \pi} \sqrt{\frac{g}{h}}
\end{aligned}
$$

を表はした直線である。份実驗は種々の底角を持つこの種 の铃器に対しても行つた。文山形断面を持つ容器に対して も㨁径及び深さを変へて実驗を行つたが、それ等の結果は 省略方吕。

以上の実驗に依り種んなる容器內における液体波動の自 然振動数が知られた故、次に斯吕液体波動を動吸振器とし て用ひる場合の試驗を行つた。それに用ひた装置は、第 90 図の如く、第 85 図に示す裴置の連結棒 $G$ の代りにばね $S_{1}$ を置き、叉こえれと対称の位置にばね $S_{2}$ を置いたもので 市る。

第 90 四仁於て、容器に或量の水を入れ、水面に腺間が 生じない椂に蓋をして電動機を回轉すれば、容器 $A$ は第 91 図に破線で示方如き共振礼振動学行ふ。このとき容器 の蓋を水面上り適當に離せば、水の表面に波動を生じて動 四振器の作用をなし、この之きの振幅曲線は実線の如くな る。即ち或振動数の所で振幅は零に近くなり、之の前後に 於て共振れを起し大きな振幅になつてるる。この現象は淮 体波動が動吸振器として満足に作用してるることを示すも

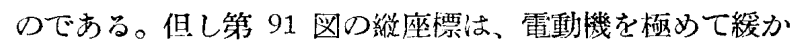
に回轉したときの容器の所謂、靜振幅 $A_{0}$ に対少る振幅 $A$ の割合、即ち倍窈它取つてある。

第 92 図恬容器の蓋に水面上の距離 $t$ を極めて僅から つ変へて行つたときの振幅曲線である。この距離が小なる ときは水波か蓋に衝突してエネルギの一部を失ふから所謂 摩摖制振器の作用がある訳である。距離 $t$ を適當にすれ ば最大层幅の倠を或程度まで小さくは出未るが、併し最小 振幅の大きさは大となっ。

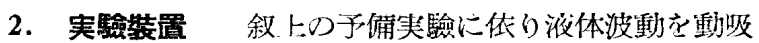
振器に利用して有效なことが知られたので、次にこれるク

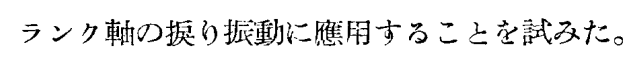

第 93 図 (a) はこの実驗に用ひた装置を示し、その中 $A, B, C, E, F, G$ は振子型動吸振器の実驗裝置 (第 53 図) 上全く闹様ですり、只吸振器 Dが異ならのみである。第 93 図(b) は裝置外観の竄賈でする。

\footnotetext{
(4) H. Lamb, Hydrodynamics, fth ed. (1932), p. 443.
}
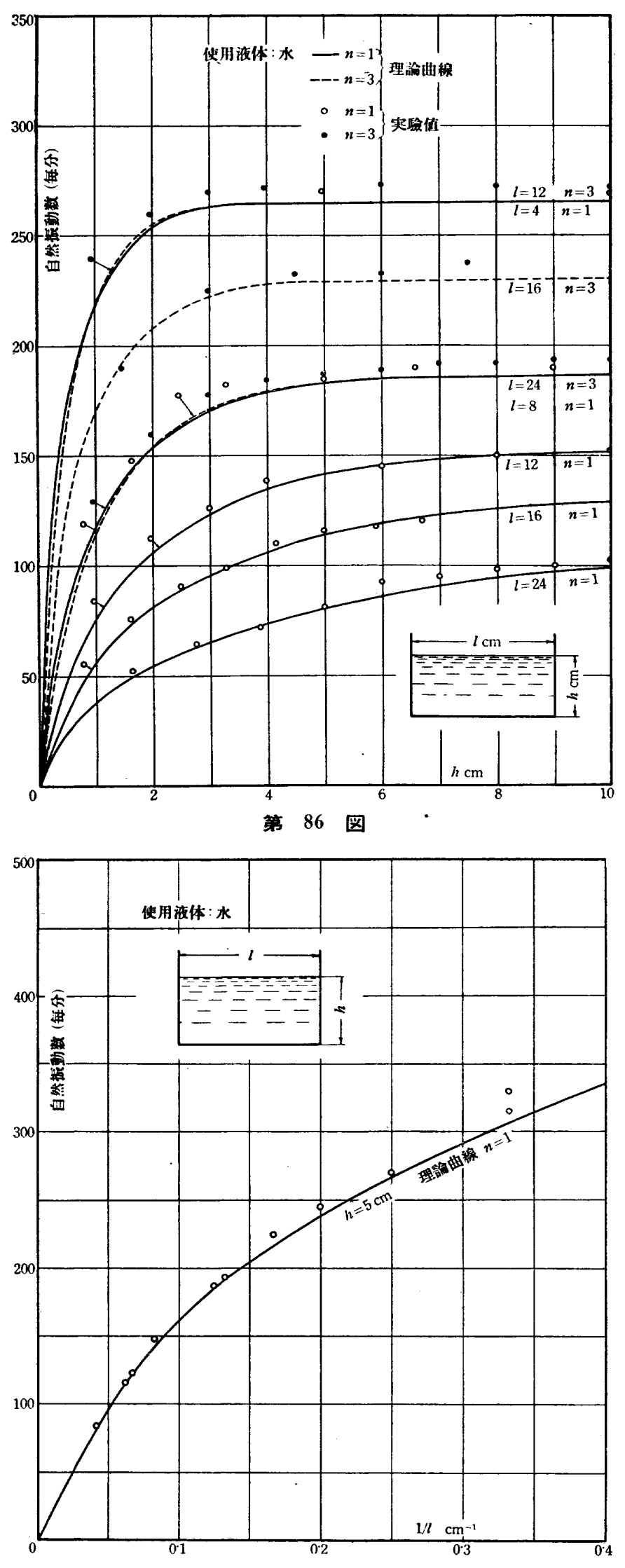

第 $87^{-}$，図

第 94 図は吸振器の断面図を示し、A は軸に国宗した貿 量であり、これに溜体 $C$ (この場合に法常に水鉭）部分的

[昭 和 16 年 8 月 


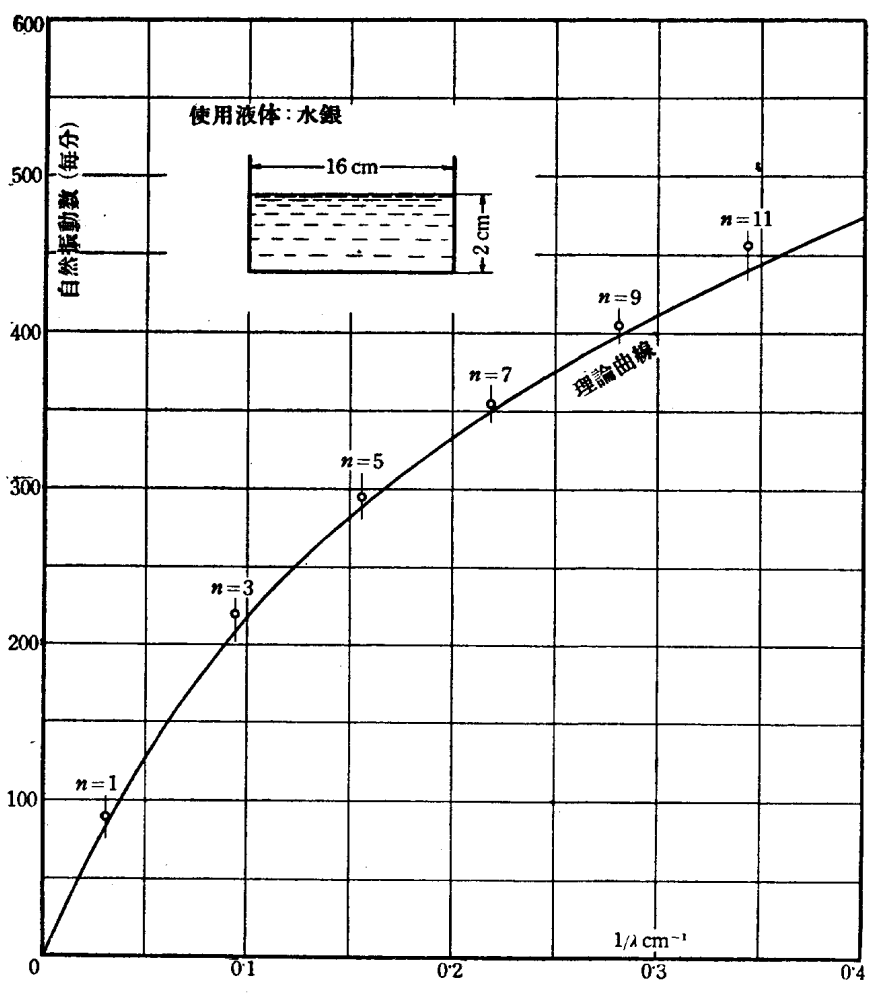

第 88 图

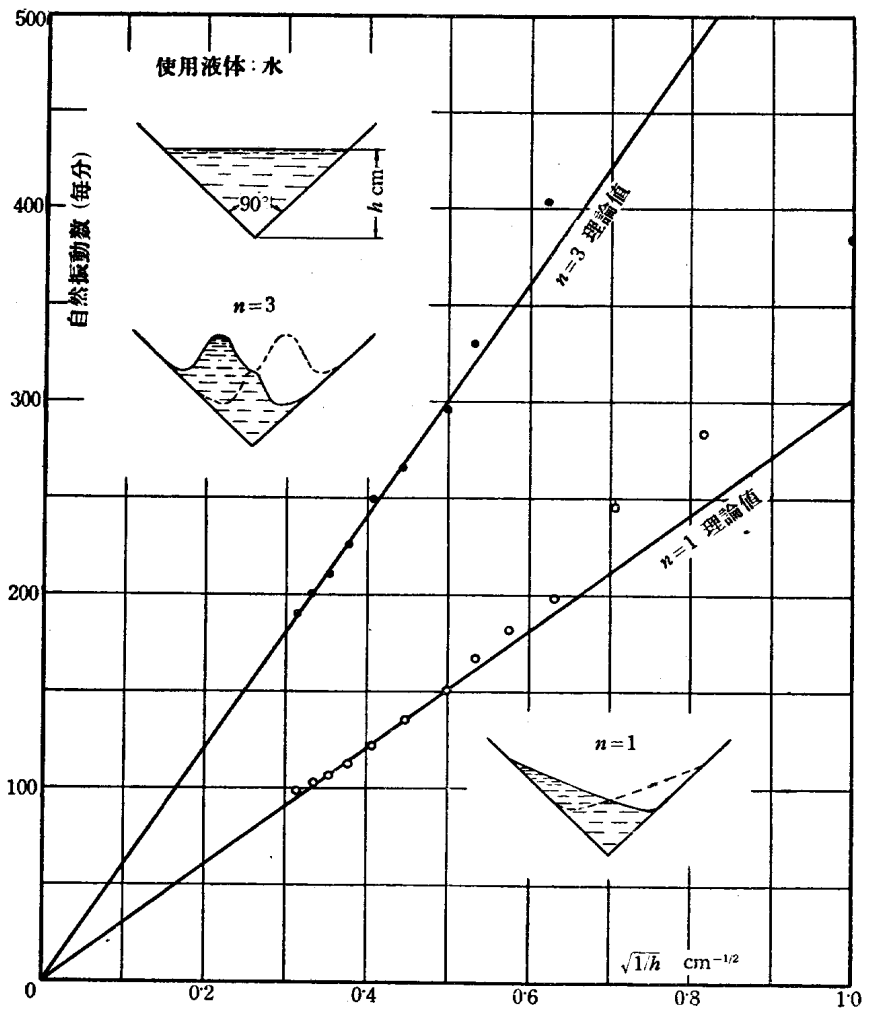

第 89 图

に充たした容器 $B$ て取付ける。容器 $B$ の回轉軸の中心よ りの距離は間隔片 $D$ に依て変へることが出未る。文そのと き生小る回轉質量の不釣合は、質量 $E$ を調整するここに依 て除かれる。

第 95 図はこの実驗に使用した液体容器る示す。容器は軟 鋼より所定の形狀に制り出したもの（厚さ $50 \mathrm{~mm}$ ) の両側 第 7 卷第 28 号 (第 1 部)]
に同じく軟鋼撆の蓋をボルト䋨めしたもので、 $a$ 型（中央の 仕切の厚さは $10 \mathrm{~mm}$ である)、 $b$ 型、 $c$ 型の 3 種を製作し、 更に $b$ 型容器の幅を狹めて $d$ 型とし、又 $c$ 型容器の中央 に厚さ $10 \mathrm{~mm}$ の仕切を入れて $e$ 型とした。台 $b$ 型容器に 入れた水銀の量を 2 種としたのでそれる區別するために $b_{1}$, $b_{2}$ とした。第 95 図下図の写湏は左より $a$ 型、 $b$ 型、 $e$ 型 を示す。第 95 図に示す吸振器の各種容器を取付けた場合の 回轉の中心の周りの慣性モーメント $I_{1} g$, 水銀の重量 $W$ 及 び樑さ $h$ は第 6 表の如くである。

第 6 表

\begin{tabular}{l|l|l|c}
\hline & $W(\mathrm{~kg})$ & $h(\mathrm{~cm})$ & $I_{1} g\left(\mathrm{~kg} \cdot \mathrm{cm}^{2}\right)$ \\
\hline$a$ & $2 \cdot 78$ & $2 \cdot 7$ & $2632\left(r_{1}^{\prime}=13 \cdot 5 \mathrm{~cm}\right)$ \\
$b_{1}$ & $3 \cdot 20$ & $2 \cdot 5$ & $3254\left(r_{1}^{\prime}=15 \cdot 2 \mathrm{~cm}\right)$ \\
$b_{2}$ & $3 \cdot 70$ & $3 \cdot 0$ & \\
$c$ & $2 \cdot 78$ & $4 \cdot 0$ & $4231\left(r_{1}^{\prime}=17 \cdot 5 \mathrm{~cm}\right)$ \\
$d$ & $2 \cdot 203$ & $2 \cdot 0$ & $2165\left(r_{1}^{\prime}=12 \cdot 3 \mathrm{~cm}\right)$ \\
$e$ & $2 \cdot 456$ & $4 \cdot 0$ & $2531\left(r_{1}^{\prime}=14 \cdot 9 \mathrm{~cm}\right)$ \\
\hline
\end{tabular}

但し $b_{2}$ 型の $I_{1} g$ の值は求めてないが、これは $b_{1}$ 型のそれ より容易に計算が出来る筈である。これ等の $I_{1} g$ の值は容 器內に水銀が固体の如く入つてるると考へた場合の值であり、 又それは容器の回轉の中心 $O^{\prime} よ り の$ 距離に依て変るが、上 記の值は容器底部の中点 $M$ の $O^{\prime}$ よりの距離 $r_{1}{ }^{\prime}$ (第 96 図）の值が括弧內に記入した如き大きさの時のものである。 又実際には上記吸振器の㥽性モーメントの他に、クランク軸、 連桿、往復質量等に基づく慣性モーメント $17 \mathrm{~kg} \cdot \mathrm{cm}^{2}$ (往復 質量を $1.837 \mathrm{~kg}$ として) が別に加はる。向この波動型吸振器 の実驗に於ては、往復質量は、第 103 図 $\left(b_{1}-3, I I\right)$ 及び 第 104 図 $\left(b_{2}-3, I I\right)$ の $0.575 \mathrm{~kg}$ 以外は全部 $1.837 \mathrm{~kg}$ と した。

第 6 篩に於て求めた近似理論式 (81) より

$$
\nu_{0}^{2}=m \frac{r_{1}^{2 m}-r_{0}^{2 m}}{r_{1}^{2 m}+r_{0}^{2 m}}
$$

は容器の扇形中心 $O$ と回轉の中心 $O^{\prime}$ とが一致する場合で

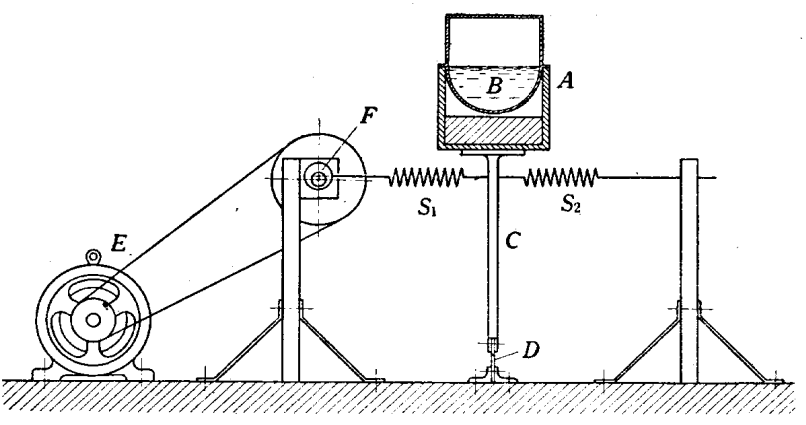

\section{0 図}

ある。若しこの両中心が第 96 図の如く一致しない場合には、 $m$ を定める式

$$
\dot{m}=\frac{n \pi}{\theta_{1}} \quad(n=1,3,5, \ldots \ldots)
$$

の中の角 $\theta_{1}$ を如何に取れば良いかに迷ふ。それを近倾的に 決定方るには容器の両本径面に及す液の圧力差の中心 $C_{1}$ 及 

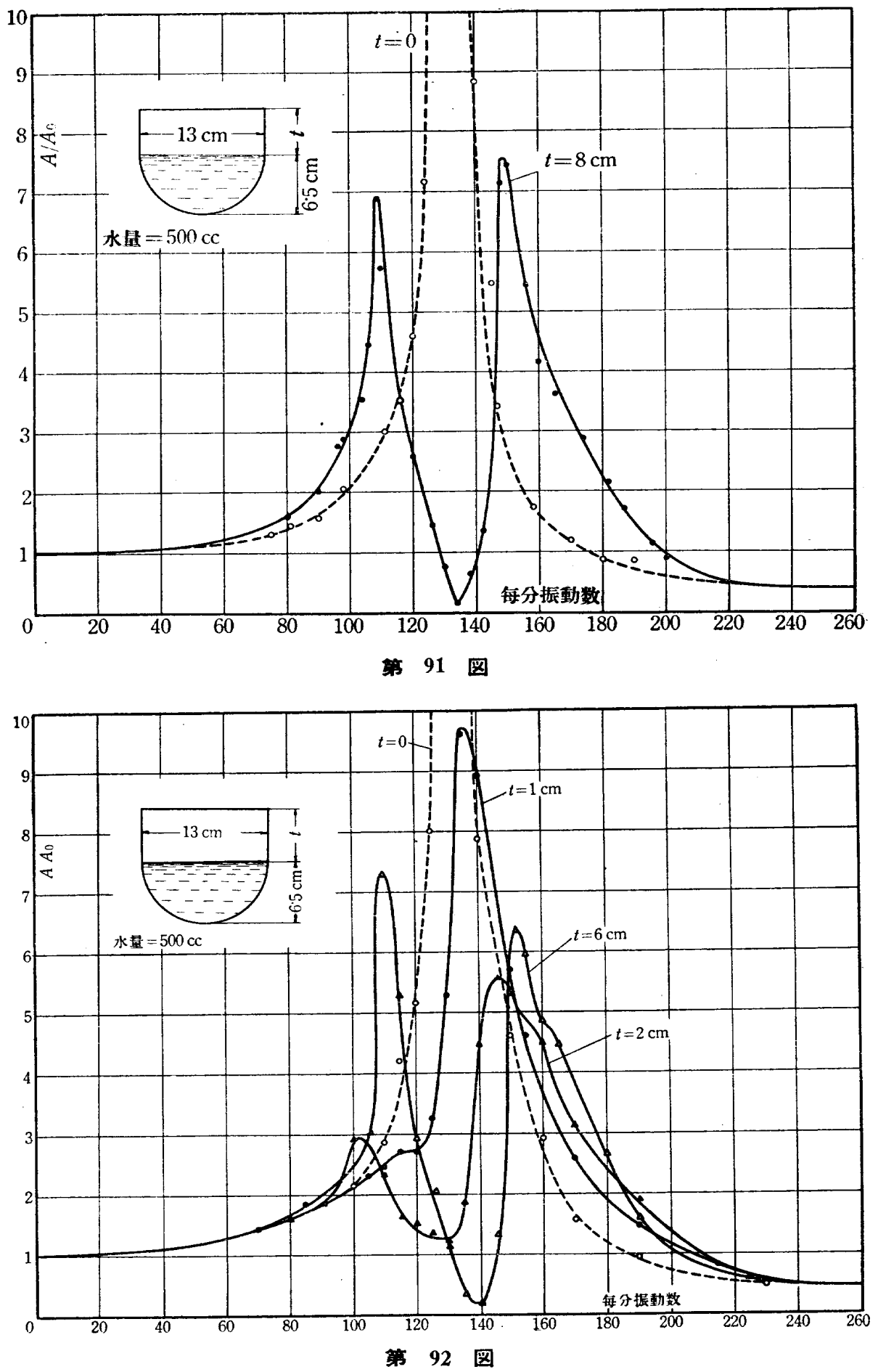

び $C_{2}$ る求め、その 2 点と问轉の中 心 $O^{\prime}$ とを結ぶ直線のなす角を $\theta_{1}$ と すればよい。即ち、商器の仙伴徍面 に及す液の圧力差を $\Delta p$ とすれば、 式 (69) 及び $(77)^{\prime \prime} よ り$

$$
\begin{aligned}
& \Delta p=\left(p_{m \theta=n \pi}-p_{m \theta=0}\right) \\
& (n=1,3,5 \ldots \ldots) \\
& =\frac{\Omega C_{1}}{2 \omega}\left(r^{m}+\frac{r_{1}^{2 m}}{r^{m}}\right)
\end{aligned}
$$

第 96 図に示方如く、回轉中の水 銀の表面の回轉中心 $O^{\prime}$ 上りの牛径 を $r_{0}$ とし、㕛液量に変化を生じな い様に容器の底面を $O^{\prime}$ を中心とす る円柱面で置換へたときの牛径を $r_{1}$ と方る。然るときは、代力差の中心 の $O^{\prime}$ よりの半烽 $r_{c}$ 㹥次式で表は される。

$r_{c}=\frac{\int_{r_{0}}^{r_{1}} \Delta p r d r}{\int_{r_{0}}^{r_{1}} \Delta p d r}$

$=\frac{\frac{r_{1}^{m+2}-r_{0}^{m+2}}{m+2}-\frac{r_{1}^{2 m}\left(r_{1}^{2-m}-r_{0}{ }^{2-m}\right)}{\frac{m-2}{r_{1}^{m+1}-r_{0}^{m+1}}}-\frac{r_{1}^{2 m}\left(r_{1}^{1-m}-r_{0}{ }^{1-m}\right)}{m+1}}{m+1}$

今

$$
x=\frac{r_{0}}{r_{1}}
$$

と置けば、(243)より

$$
\begin{aligned}
\frac{r_{c}}{r_{0}} & =\frac{\frac{x^{-1}-x^{1+m}}{m+2}-\frac{x^{-1}-x^{1-m}}{m-2}}{\frac{1-x^{1+m}}{m+1}-\frac{1-x^{1-m}}{m-1}} \\
& =f(x, m)
\end{aligned}
$$

の如く $r_{0} / r_{0}$ は $m$ 之 $x$ の函数上 なり、更に滩の深さに対する表面よ り压力差の中心汽の距離の割合も次 の如く $m$ と $x$ の函数となる。

$$
\begin{aligned}
y & =\frac{r_{c}-r_{0}}{r_{1}-r_{0}} \\
& =\frac{f(x, m)-1}{x^{-1}-1}=F(x, m)
\end{aligned}
$$

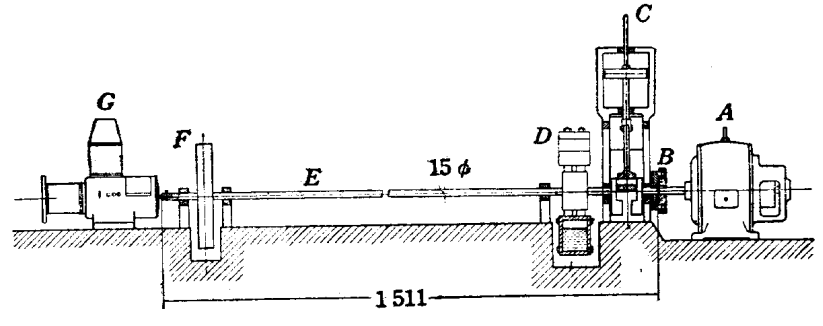

(a)

第 93 図 $(a)$

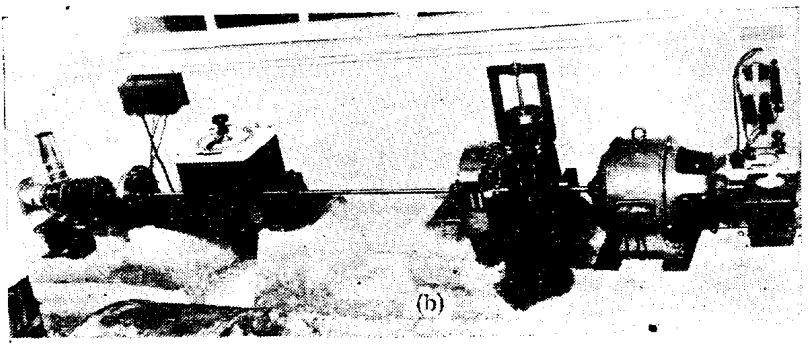

93 圆 (b) 
故に若し $x$ の值を仮定すれば、(246) の左辺は $x$ のみの 函数となる。第 97 図の曲線 $\alpha, \beta, \gamma, \delta, \varepsilon$ は夫夕 $x=$ $0 \cdot 710,0 \cdot 740,0 \cdot 756,0 \cdot 770,0 \cdot 783$ に対古当 $y$ と $m$ の関係
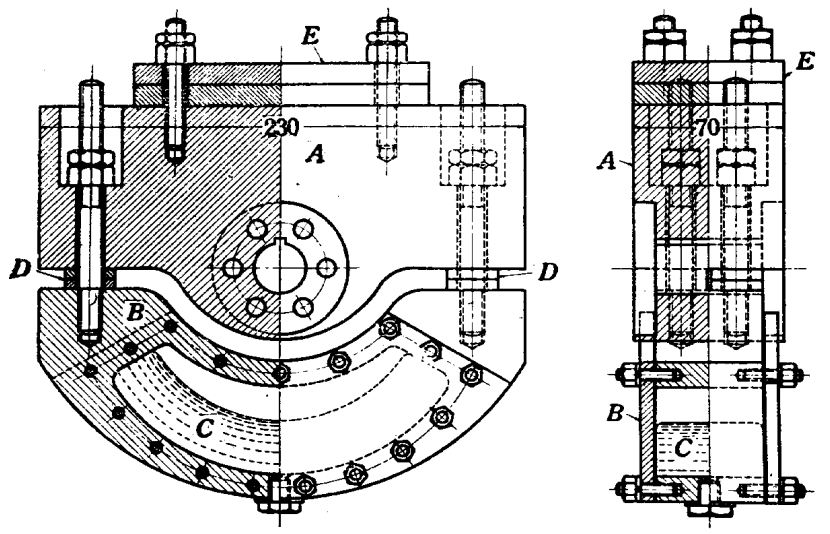

第 94 图
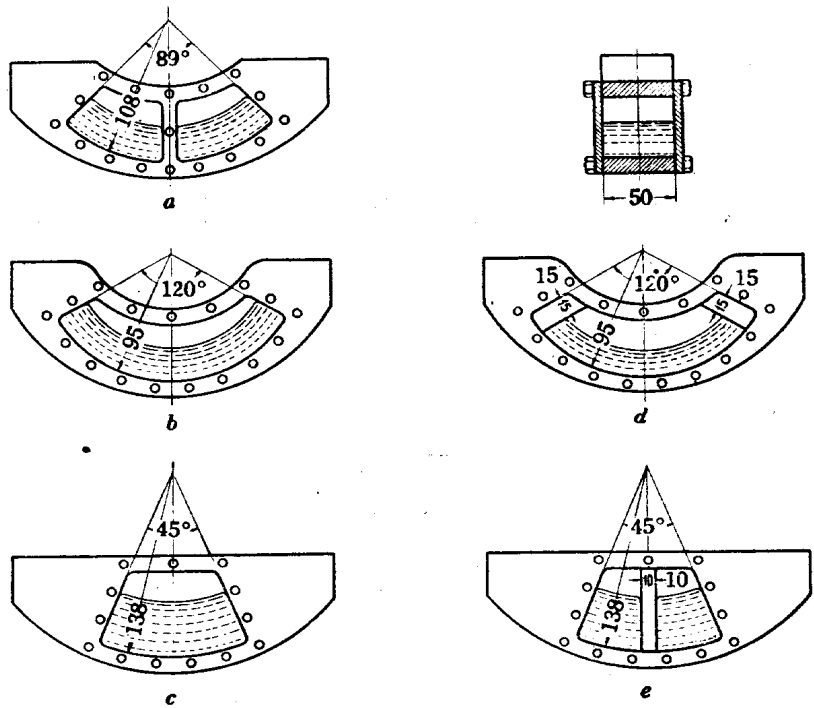

(a)

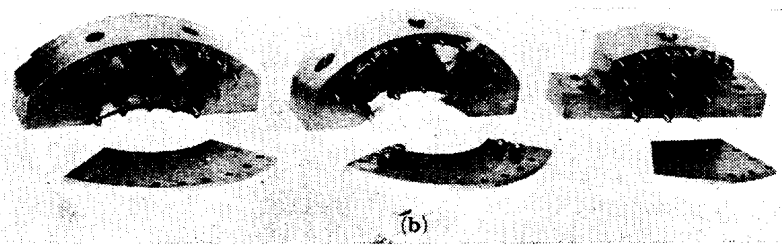

\& 95 圆

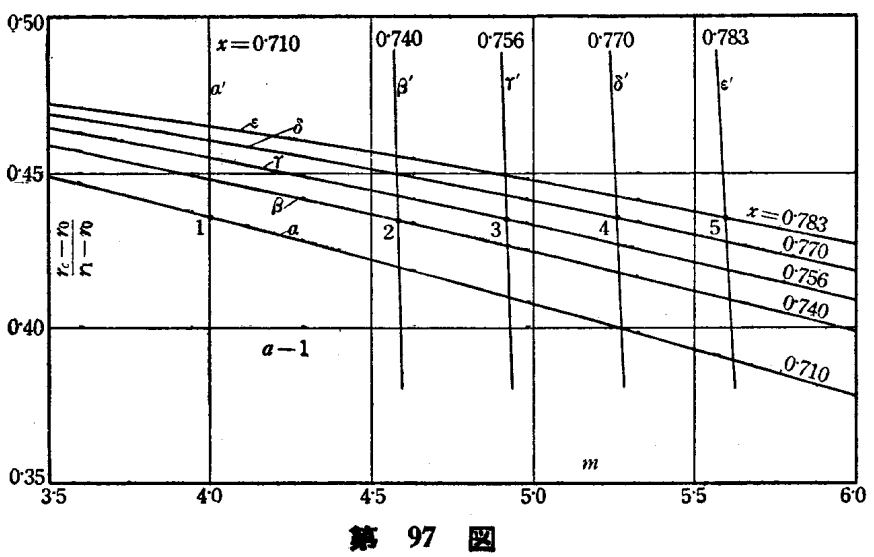

第 7 卷第 28 晏(第 1 部)]
を示すものである。これを見ると玏差の中心の位置は、深 さの中央よりも表面に近いのみならす、 $x$ が小な程又 $m$ が大なる程益: 液表面に近づくことが知られる。但しこれ等 の曲線は單に式 (244) より導いたもの、即ち回轉中心を扇形 の中心とする容器に対するものであつて実際の容器の形狀に は全く無関係である。

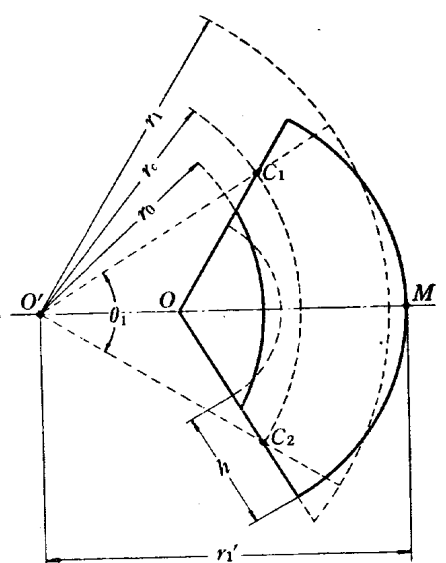

第 96 図
次に第 96 図に示す如 き実際の容器に就て、前 と京様な曲線孛作っこと が出来る。即ち $r_{1}{ }^{\prime}$ の值

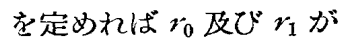
定まり、従て (245)より $x$ も決定する。 $x$ 定一定 にして置いて、点 $C_{1}$ 及 び $C_{2}$ を器壁上に移唾さ せれば式 (246) のy の值 が変り、页同時に $\theta_{1}$ も 変るから $m$ の值も変る。 に対する $y$ と $m$ の関係 斯くして一定の $x$ の值
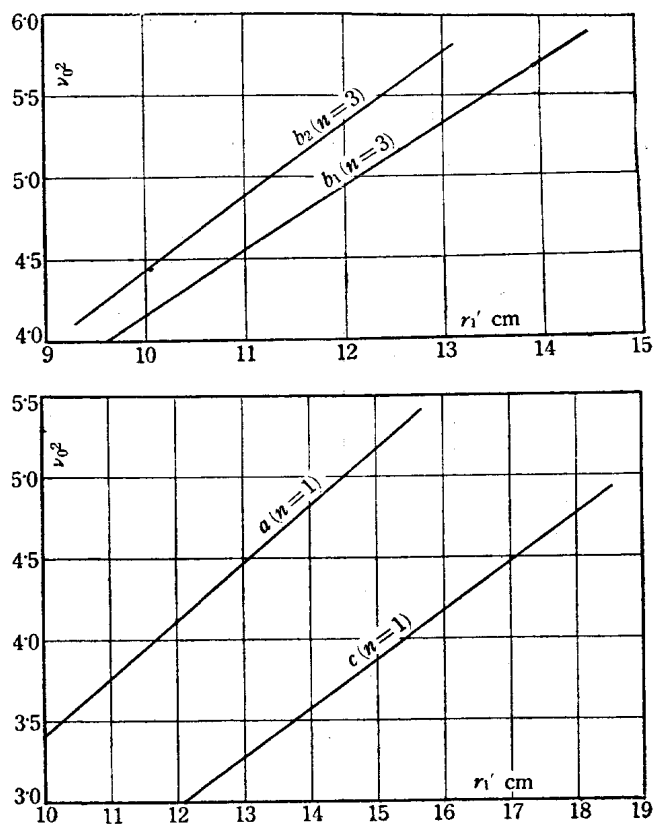

第 98 图

が得られる。第 97 図の曲線 $\alpha^{\prime}, \beta^{\prime}, \gamma^{\prime}, \delta^{\prime}, \varepsilon^{\prime}$ は $a$ 型容 器の場合に前と同じ $x$ の值 $x=0 \cdot 710,0 \cdot 740,0 \cdot 756,0 \cdot 770$, 0.783 に対与る $y$ と $m$ との関係である。容器の扇形中心 $O$ 上回轉中心 $O^{\prime}$ (第 96 図) とが一致するときは、王力美の中 心位置に無関係に $m$ の值が定まる。第 97 図の $a$ 型容器に於 ては闭中心の一致するのは $m=4$ の場合であるから、 $m=4$ に和ける $\alpha^{\prime}$ の線什直立した直線となつてるる。故に曲線 $\alpha$ 之 $\alpha^{\prime}, \beta$ 之 $\beta^{\prime}, \ldots \ldots$ の交点 $1,2,3,4,5$ は $a$ 型容器化 対して式 (244) の満足される関係を與へる。 $x$ が定まれば $r_{1}{ }^{\prime}$ が決定し、又 $m$ が定まれば (243) より $\nu_{0}^{2}$ も求められ

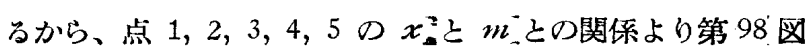
及び第 99 図に示す如き $\nu_{0}{ }^{2}$ と $r_{1}{ }^{\prime}$ との関俰が得られる。第 
97 少の曲線は $a$ 型商器に対するものであるが、他の型の谷 器に対しても同様な曲線を画いて第 98 図及び第 99 図に示 文各種容器に対する $\nu_{0}{ }^{2}-r_{1}{ }^{\prime}$ の曲線索求めたのである。

実驗の方法は、所定量の水銀忞封入した容器の回轉の中心 よりの距離 $r_{1}{ }^{\prime}$ を変へ乍ら、振子型吸振器の場合上全く同様 に振動図形を記錄して、振幅 $A_{0}{ }^{\prime}$ と $r_{1}{ }^{\prime}$ との関係を定める。
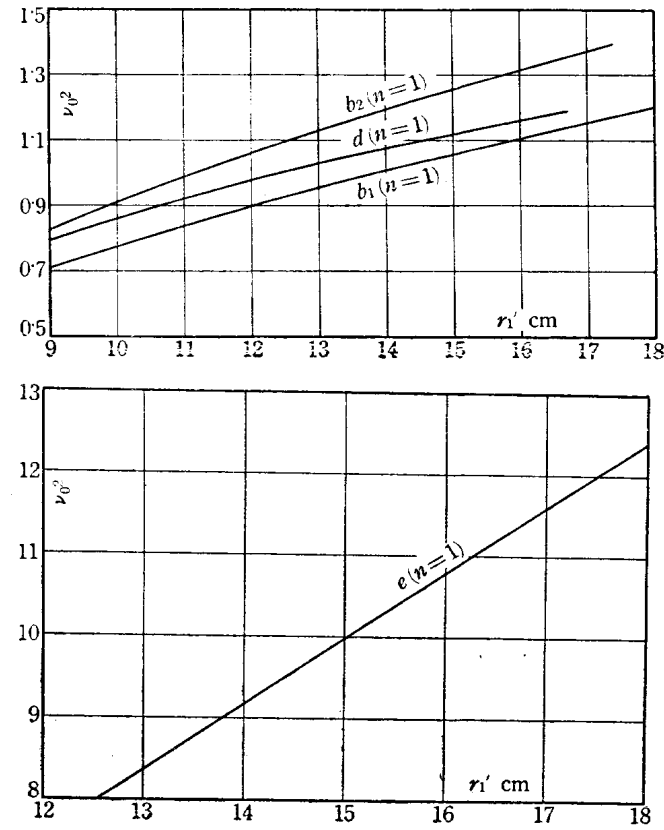

第 99 図

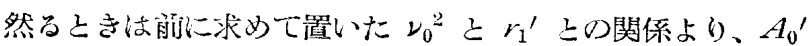
と $\nu_{0}{ }^{2}$ と関係も定められる。

第 93 図は軸を橫置した場合の実驗装置を示すが、振子型 吸振器の場合にも述へたた如く、この装置全体をこのま〉直立

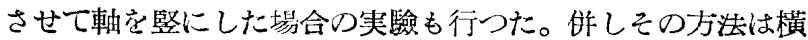
軸の場合と全く同様である。

3. 実驗結果 第 7 蓈に於て庥べた如く、横軸の場合に 1 次の振動を吸收宁動吸振器には重力の作用が强く影響す っので、1 次吸推器の場合さそれ以外の吸振器の場合と分け て取报ふ必要がある。

a. 1 次以外の振動を吸收する吸振器の場合 第 100 図の 破線は吸掂器內の水銀を固体質量に依て置換へた埸合、即ち 普通の軸に対する共振え曲線である。文実線は吸振器を作動 狀態にしたときの振幅曲線で方つて、この場合の吸振器は 2 次の回轉モーメントを吸收方尚如く調整してある。この図々

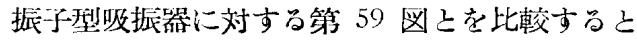

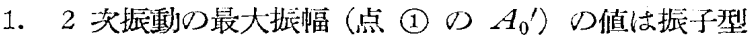
つ場合に比して甚だしく小さくなつてるること、

2. 振子型吸振器凹埸合には 2 次以外》 1 次、3 次、4 次等の振幅は吸振器を附加しない場合に比較して却て大き くなつてるるのに対し、波動型吸振器の場合には 2 次以外 の振幅も若干小さくなつてるること

等が知られる。この 1.0 ○性澌は液体波動》際に作用方学摩 㩒は內部摩綮のみであり且波動の振幅は小さいものであるか ら、このために起る減衰作用は小さい故上思はれる。页 2 .

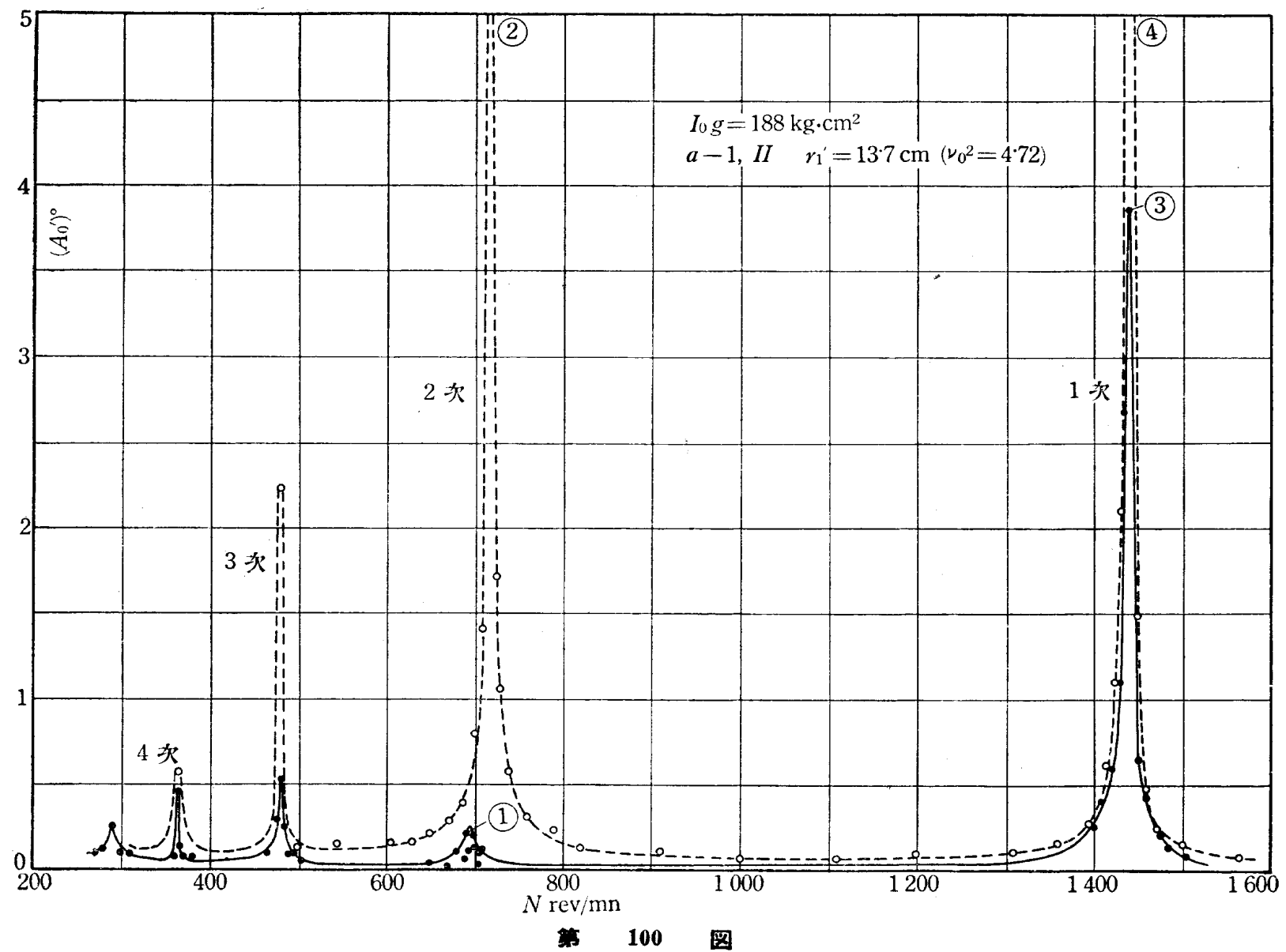

[昭 和 16 年 8 月 


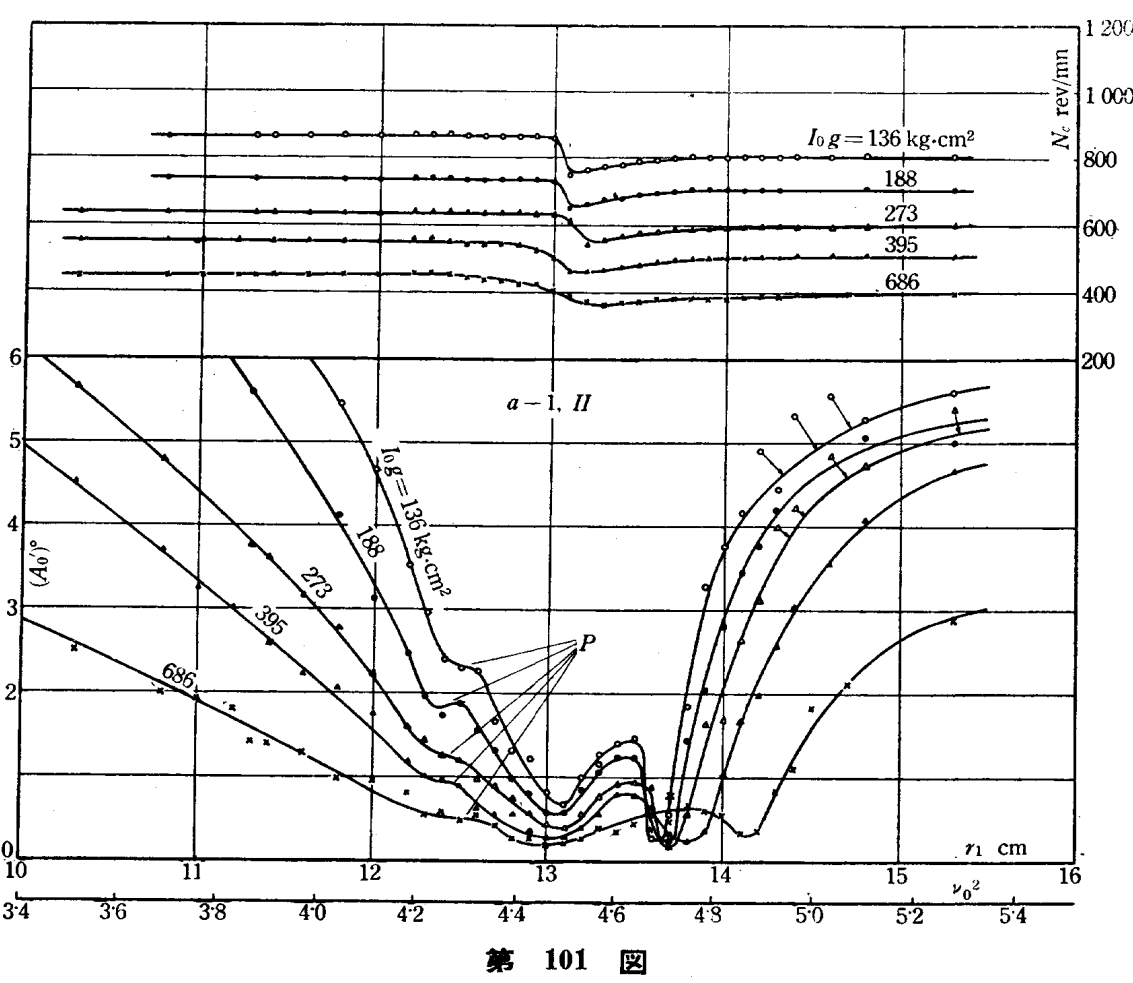

つ性質は、內部摩搖は小さい乍らも常に 規則正しく作用してるるために 2 光以外 の次数の場合も共振れ狀態に於ては相當 に減裏されるからであらう。

第 100 図の点 (1) の最大振幅を維軸 に取り $r_{1}^{\prime}$ 或は $\nu_{0}^{2}$ を橫軸に取つた曲線 は第 101 図乃至第 105 図に示される。 第 101 図は $a$ 型容器の 1 次の波 $(a-1)$ を用ひて 2 次振動 $(I I)$ を吸收した場合 に、は亦み車の慣性モーメント $\left(I_{0} g\right)$ を 種々に変へた場合の $A_{0}{ }^{\prime}$ 及びこれが起 る每分回轉数 $N_{c}$ を示す。第 102 汹は 同じく $c$ 型容器党用ひた場合、第 103 図及び第 104 図は $b_{1}$ 及び $b_{2}$ 型容器 D 3 矢の波 $\left(b_{1}-3, b_{2}-3\right)$ を用ひて 2 次振動 $(I I)$ を吸收した場合、第 105 図 は $e$ 型容器の 1 次の波 $(e-1)$ を用ひて 3 次振動 $(I I I)$ を吸收した場合である。 往復質量は第 103 図及び第 104 図は $0.575 \mathrm{~kg}$ であり、これ以外は $1.837 \mathrm{~kg}$ である。

これ等の曲線を見れば
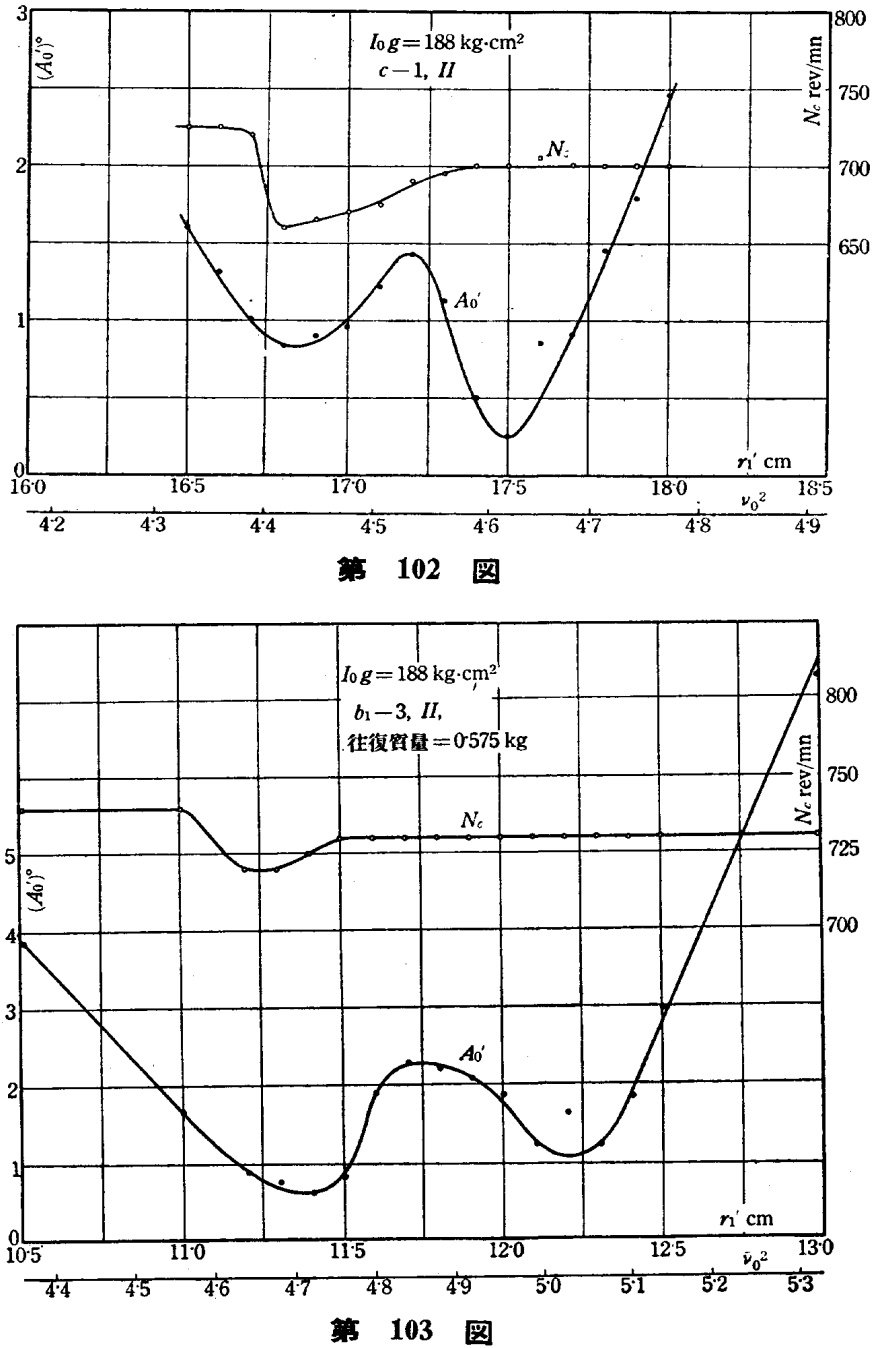

1. $A_{0}{ }^{\prime}$ の曲線の極小点は 2 筬所にある。

2. その第 1 の極小点は同じ容器では $I_{0} g$ の值に無関 係に一定の $\nu_{0}^{2}$ の值の所にあり且ここでは $N_{c}$ の值が大 なる変化をなしてるる。

3. 第 2 の極小点の起る $\nu_{0}^{2}$ の值は $I_{0} g$ の值に依て 変つてるる

等の性質が知られる。波動型吸振器の場合には振子型吸振器 に対する如き計算を行ふことは出来ないが、觧記の諸性質は 振子型吸拉器の性質と大体同一のものと思はれる。叙上の典 線の第 10 極小点は、振子型吸振器の場合には軸の共振れを 起す速度 $\omega_{c}$ が 0 となっ（減衰のない場合に）ために起つた のであるが、波動型吸振器の場合にも同様と想像される。乙 のときの $A_{0}{ }^{\prime}-N$ D曲線は第 106 図に示方如く甚だ緩慢 な变化をなしてをり、第 2 の極小点附近の $A_{0}{ }^{\prime}-N D$ 曲線の形狀は、第 100 図の点 (1) 附近の如く変化が急激であ る。性質 2. 及び 3. の倾向は振子型吸振器の埸合と全く同 椂である。佾第 105 図の曲線は 3 文振動を吸收した結果で あっが、この場合にも不明膫乍ら鬼に角 2 䇴の極小点が現は れてるる。

第 107 図は㹂軸に $a$ 型容器の吸振器尤使用した場合であ り、これと条件の等しい第 101 図の曲線とを比較して見ると、 その主なる性質には変化がないが、第 2 大的の変化、例へば 橫軸の場合には点 $P$ の附近に曲線つ段があるのに対し、㹂 軸の場合にはこれより全然異なる点 $Q$ の附近に段を生じて るる等の差遠が見られる。これ等の現芜の原因は、勿諭重力 の作用の有無にあると思はれる。

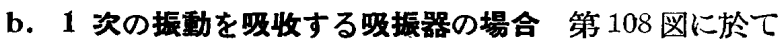
破線で示す曲線 $A$ 汁吸振器の水銀を固体で置換へた坫合、 即ち吸振器を取付けない軸の共振れ曲線であり、鉒緗で示す

第 7 卷第 28 第 1 部)] 

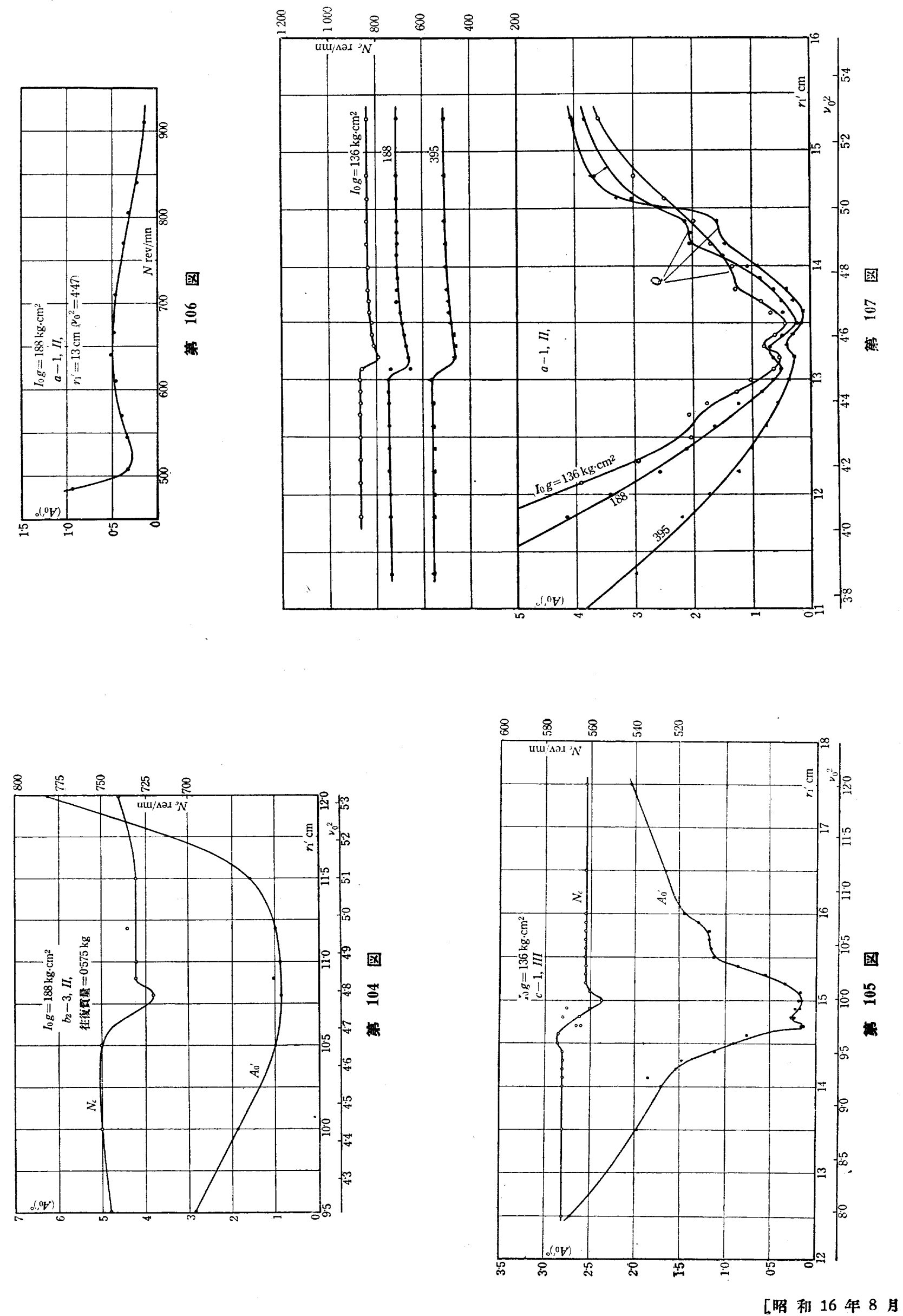


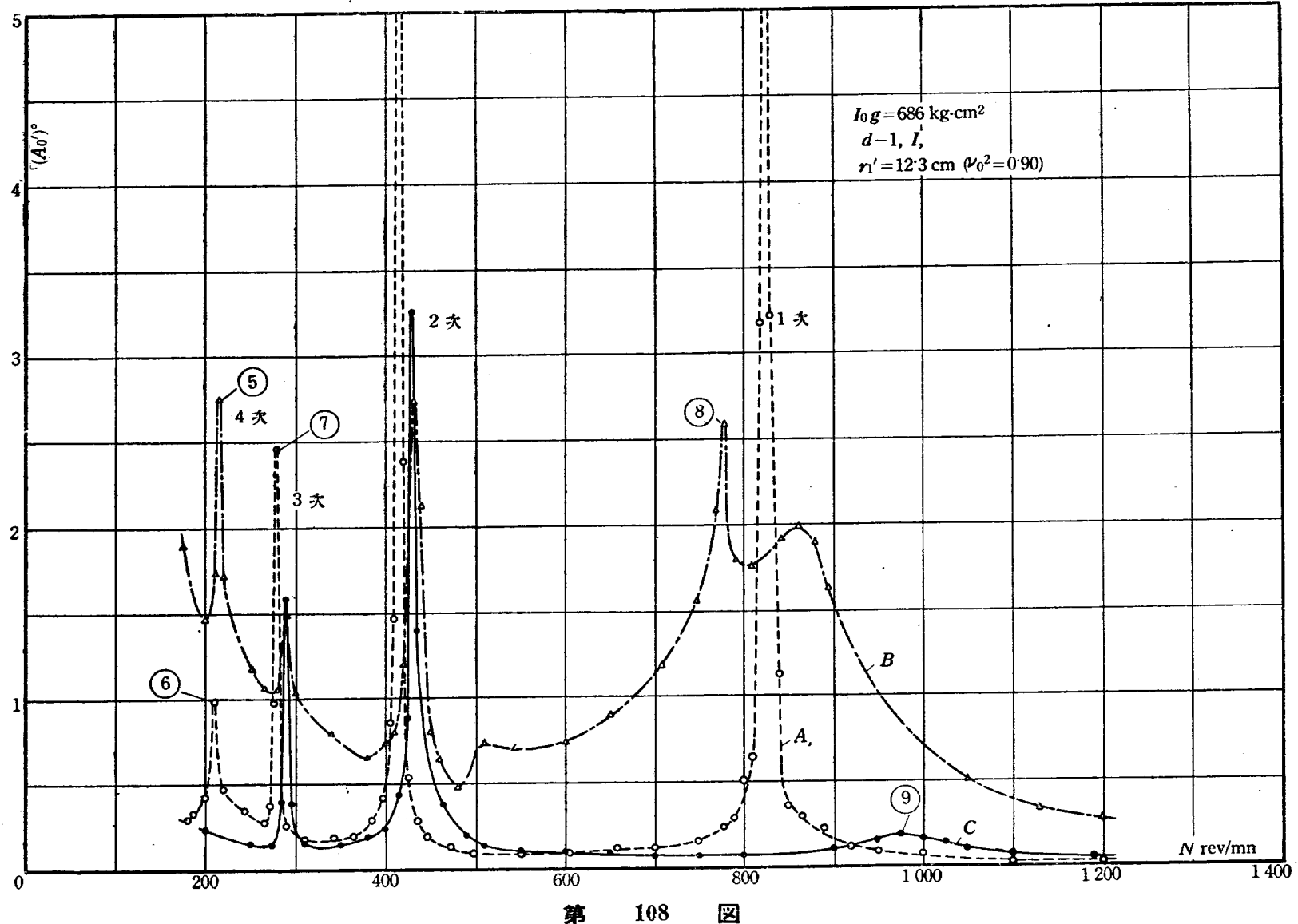

曲線 $B$ は.1 次振動引吸收 声る如き吸振器を附加した 場合である。即ち吸振器を 附加すれば 1 次振動の最大 振幅は少しく小さくなつて るらが、併し廣い範囲に亘 り大きな振幅となつてる る。これは第7 節に於て述 べた重力の作用のためであ つて、重力の作用を除去し た㹂軸の場合には実線で示 す曲線 $C$ の如く、1 次振 動は相當によく吸收されて るる。㔯曲線 $B$ が低速度 に於て特に上方に変位して るっのは 1 次振動が重つて るるためである。この事実 は振動計記錄つ極線図を見 れば明らかである。

第108図の橫軸の場合の 曲線 $B$ の 1 次振動の最大

振幅 (点 (8) の振幅) $A_{0}{ }^{\prime}$

及びそのときの $N_{c}$ を綐軸にとり $r_{1}{ }^{\prime}$ 或は $\nu_{0}{ }^{2}$ を横軸にと つた曲線を第 109 図乃至第 111 図に示方。これ等の曲線は 或範囲の $\nu_{0}^{2}$ の值に対しては相重つてるるので、斯る籁囲の $\nu_{0}{ }^{2}$ に対する $A_{0}^{\prime}-N$ の曲線は第 112 図の如く極大点が 第 7 卷第 28 㝍. (第 1 部)]

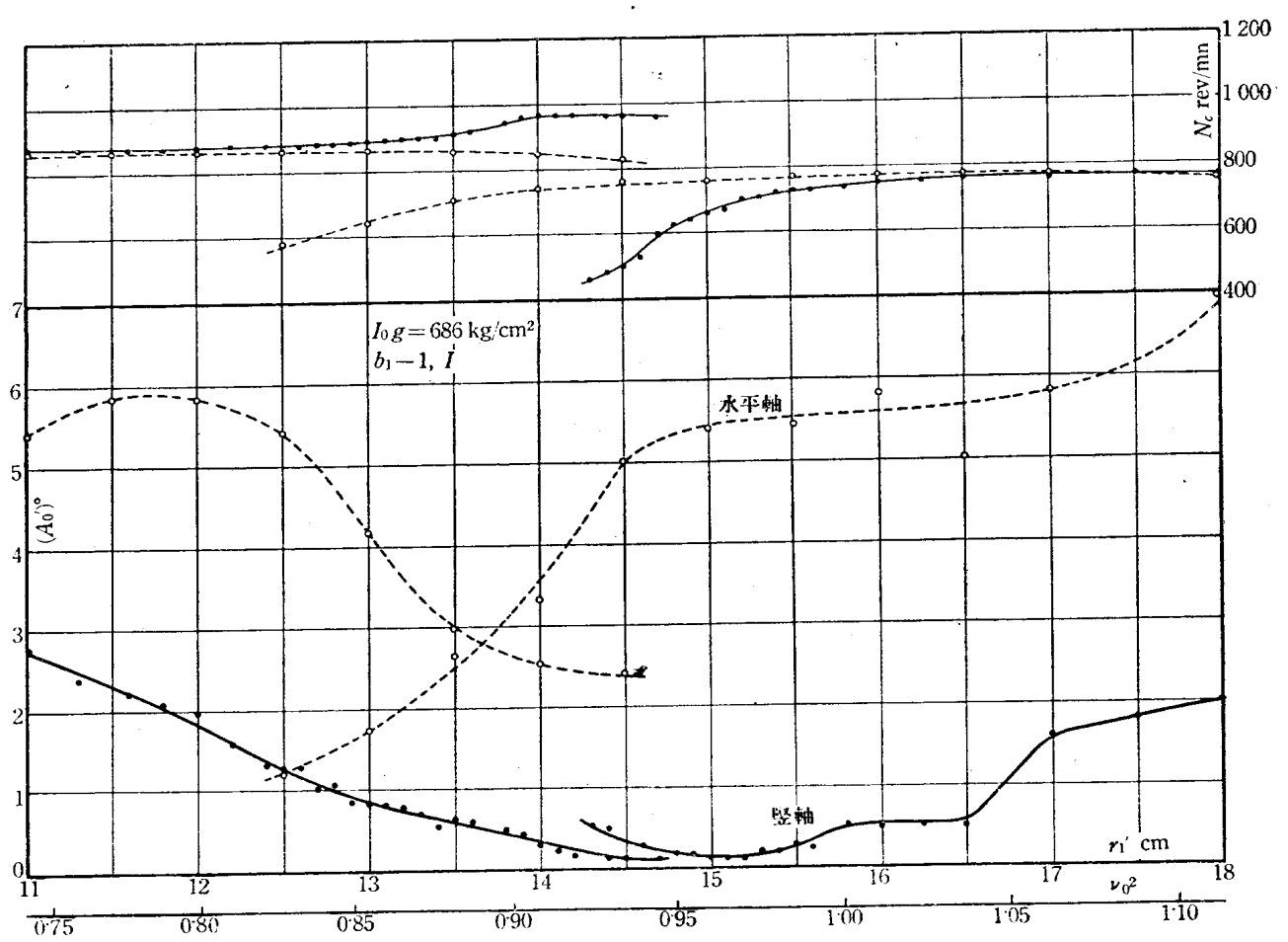

第 109 図

2 筒ある。又この範围外の $\nu_{0}^{2}$ に対方る $A_{0}^{\prime}-N$ の曲線 (水平軸) は第 113 図の如く極大点が 1 䇢のみである。

第 109 図には同じ狀態の 堅軸に対する曲線も示してあり、 吸振器が満足に作用してるるのが知られる。・文第 111 図に 
, $\mathrm{I}-52$ 谷下市松

第 7 表

\begin{tabular}{|c|c|c|c|c|c|c|}
\hline 図番号 & 軸估置 & $\begin{array}{r}I_{0 g} g \\
\mathrm{kgcm}^{2}\end{array}$ & $\begin{array}{l}\text { 容器 } \\
\text { 型式 }\end{array}$ & $\begin{array}{c}\text { 波動 } \text { 次数 } \\
\text {. }\end{array}$ & $\begin{array}{l}\text { 振動の } \\
\text { 炎数 }\end{array}$ & $\nu_{0}^{2}$ \\
\hline 100 & 横 & 188 & $a$ & 1 & $I I$ & $4 \cdot 72$ \\
\hline 101 &.$\prime$ & $\begin{array}{l}136 \\
188 \\
273 \\
395 \\
686\end{array}$ & J" & J & y & \\
\hline $\begin{array}{l}102 \\
103 \\
104 \\
105\end{array}$ & $\begin{array}{l}y \\
y \\
y \\
y\end{array}$ & $\begin{array}{c}188 \\
\prime \prime \\
\prime \prime \\
1.36\end{array}$ & $\begin{array}{l}c \\
b_{1} \\
b_{2} \\
e\end{array}$ & $\begin{array}{l}\prime \prime \\
3 \\
1 \\
1\end{array}$ & $\begin{array}{c}\prime \prime \\
\prime \prime \\
I I I I\end{array}$ & \\
\hline 106 & "y & 188 & $a$ & "y & $I I$ & $4 \cdot 47$ \\
\hline 107 & 警 & $\begin{array}{l}136 \\
188 \\
395\end{array}$ & ." & " & $\eta$ & \\
\hline 108 & 横、竪 & 686 & $d$ & . & $I$ & \\
\hline $\begin{array}{l}109 \\
110 \\
111\end{array}$ & $\begin{array}{l}\text { 榉、堅 } \\
\text { 横、堅 }\end{array}$ & $\begin{array}{c}686 \\
\prime \prime \\
\prime \prime\end{array}$ & $\begin{array}{l}b_{1} \\
b_{2} \\
d\end{array}$ & $\begin{array}{l}\text { "y } \\
\prime \prime \\
\prime \prime\end{array}$ & $\begin{array}{l}y \\
y \\
y\end{array}$ & \\
\hline $\begin{array}{l}112 \\
113\end{array}$ & 横 & "y & $\begin{array}{l}b_{2} \\
d\end{array}$ & " & "y & $\begin{array}{l}1 \cdot 00 \\
0.92\end{array}$ \\
\hline $\begin{array}{l}114 \\
115\end{array}$ & "I & "y & '” & "y & "y & $\begin{array}{l}0.90 \\
0.95\end{array}$ \\
\hline
\end{tabular}

ま同じ狀態の㯺軸の場合の曲線が示してあるが、この場 合には $\nu_{0}{ }^{2}=0.89 \sim 0.925$ 位の範团に於ては所謂非対称 共振れの現家が見られた。即ち第 113 図乃至第 115 図 の $A_{0}{ }^{\prime}-N$ 曲線に於て速度上算の際には振幅は上方の 曲線で示される如き変化をなし、或 $N$ の所で急に振幅 は小となり、次に速度を減小して行くこきは下方の曲線 で示される如き変化をなし或 $N$ の所で始めて原の曲線 こ一致する。第 111 図の㹂軸に対する 曲線の 前記範囲 の $\nu_{0}^{2}$ に相當する実線は速度上年の際の最大振幅を示 し、文鎻線は速度下降の際の最大振幅を示す。斯る非対 称共振れの現象は、第 15 節 $b$ に 於て述へた如く、波動の変位の 3 次 の項に比例した力が作用するためと 思はれる。㑊振子型吸振器の場合の 非効称共振れ現象に於ては速度上舁 の際の振幅は速度下降の際のそれよ りも小であつたのであるが、波動型 吸振器の場合にはその反対である。 この理由は、前記変位り 3 次に比 例古る項の符号が異なるためと思は れる。

1 次の波動型吸振器を取付けた横 軸に対方号 $A_{0}{ }^{\prime} \longrightarrow \nu_{0}^{2}$ の曲線（第 109 羽乃至第 111 図）及び㹂軸に対 する同曲線（第 109 図）を見れば、 $A_{0}{ }^{\prime}-N$ 曲線に極大点が 2 簤現は れてるる。然るに振子型の場合には1筒であつた。この理由 は、振子型に対する式 (252) の中の $\omega^{2}$ の次数が波動型で

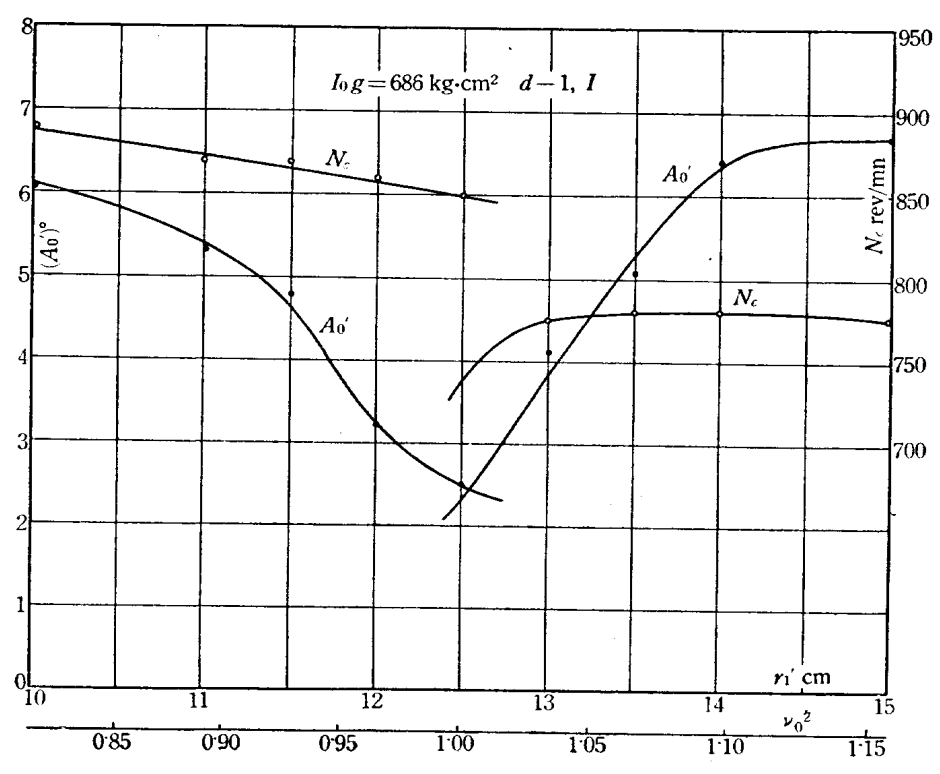

第 110 图

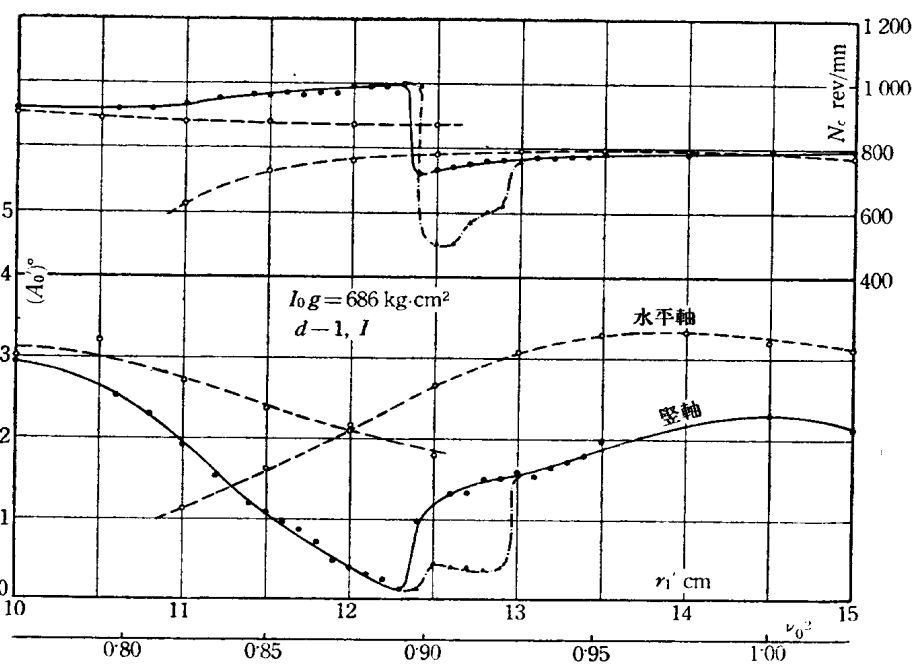

节 111 图

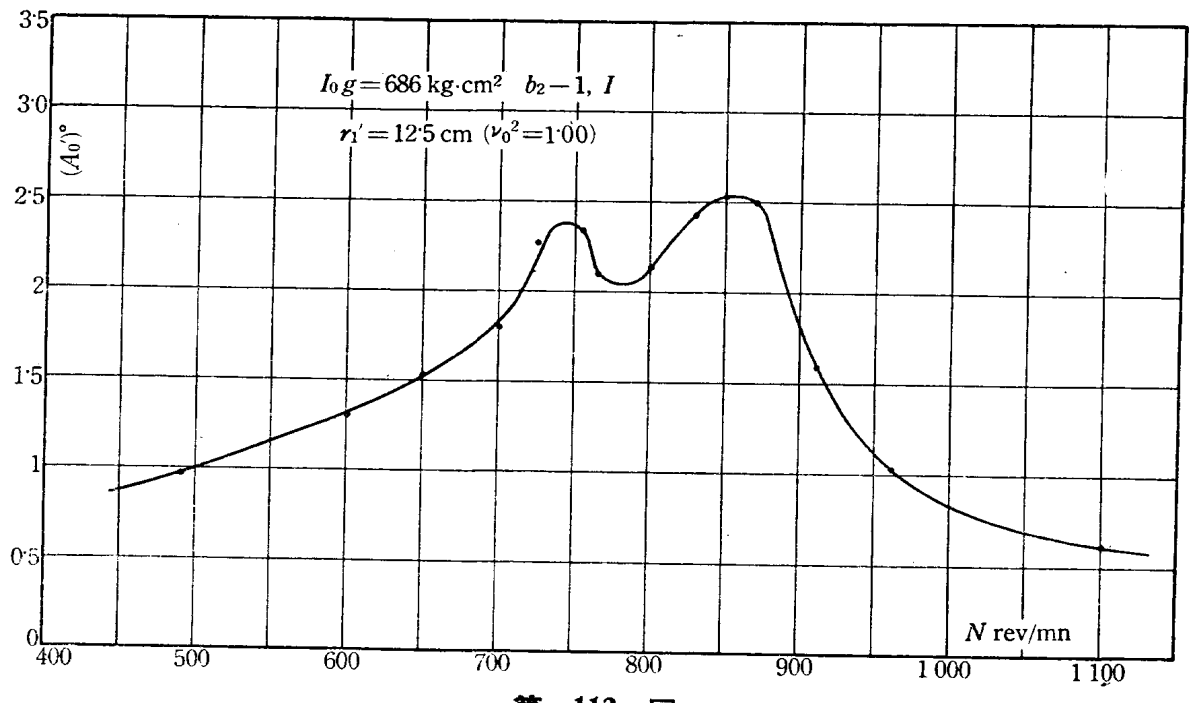

112 㘣

は振子型よりも異なるためと想像される。併し波動型は詳細 な計算が出来ないので具体的なことは制明しない。 

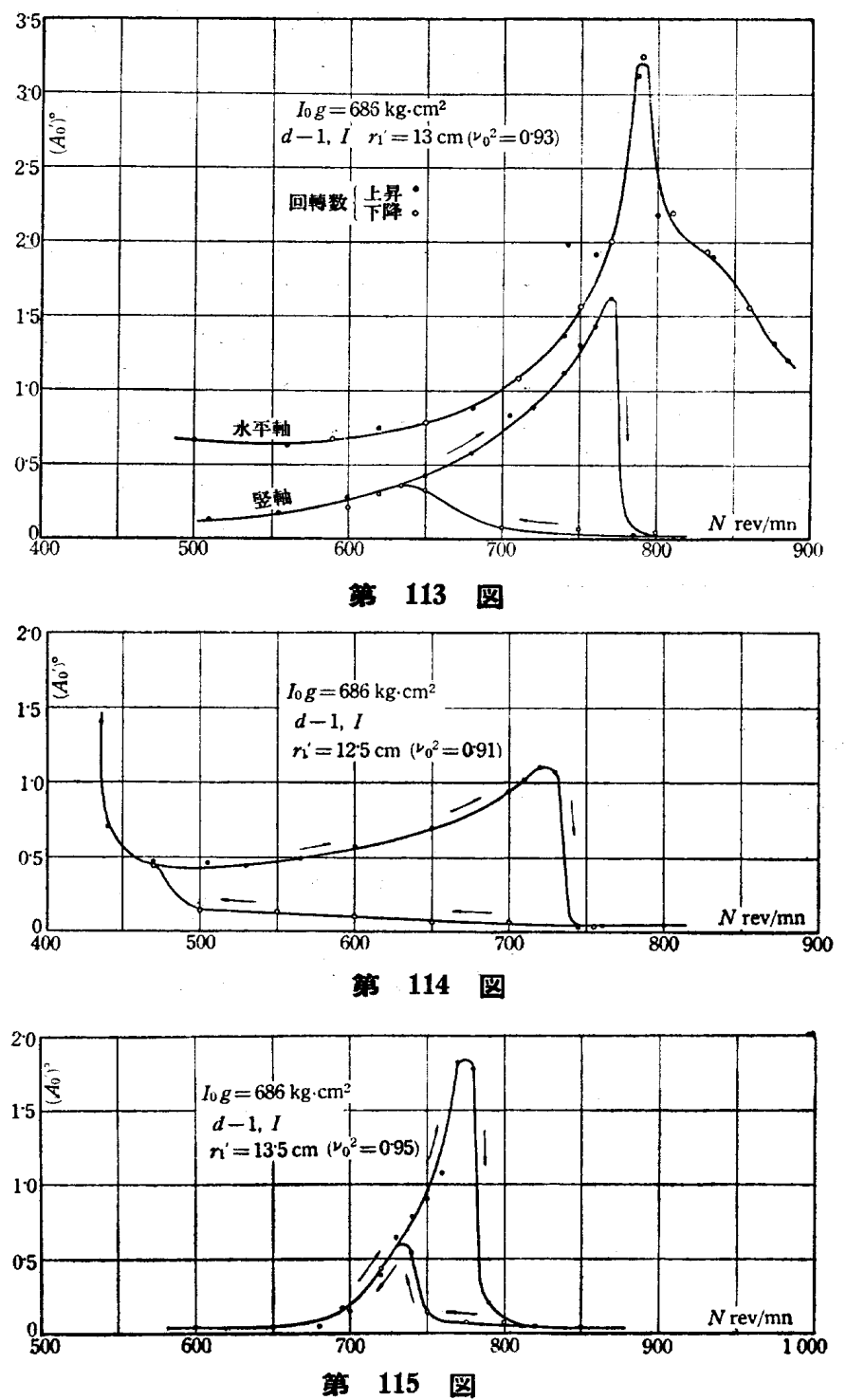

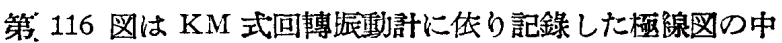
数枚る滕写して示したものである。但し図中の (1)，(2)，(3)， ...... 等刀番号は第 100 図及び第 108 図に同一の番号を附 した測定点に対するものである。

第 7 蓄汢第 100 図乃至第 115 図つ $I_{0} g$, 水銀容器つ型 式、使用した波動つ大数 $n$, 吸收した振動つ头数等の一覽装 である。

$$
\text { 17. 結㝘 }
$$

以上4報 16 節に互りクランク軸に淮用した動吸振器に就 て理淪並に実驗的考察を行つたが、次に簡單にその結言る述 ベる。

第 1 報に於ては、回轉軸心隹用し得る種々なる動吸振器の 基本的特性を明らかにし、且それが重力や摩擦に依て受ける 影響等を調へた。特心液体つ集面波動を動吸振器に憵用する ことを考案し、その計算方法を示した。

第 2 報に於ては、動吸振器を種々なる自由度のクランク軸 に應用する方法を理淪的心考察し、原クランク軸柔の振動の 型が動吸振器の附加により変化する有様を詳細に調へた。

第 7 卷第 28 号 (第 1 部)]

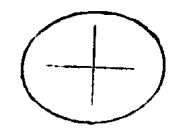

(1)

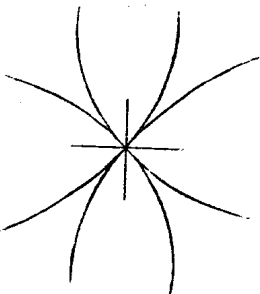

(2)

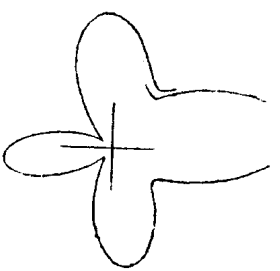

(5)

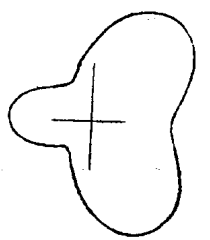

(7)

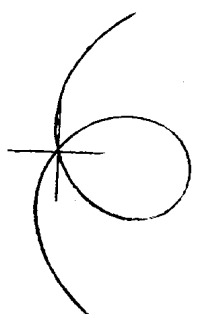

(4)

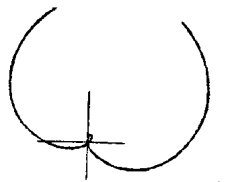

(8)

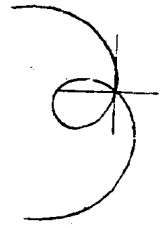

(3)

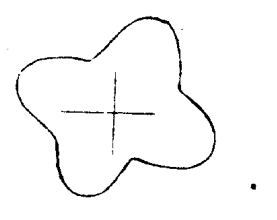

(6)

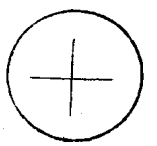

(9)
116 图

第 3 報に於てはばね型及び振子型吸振器の実驗結果を、又 第4 報に於ては波動型吸振器の実驗結果を報告し、作せてそ れに関して種々なる考察が行つた。実驗の結果て綜合して得 られる結論を列記すれば头の如くである。

1. 動吸掁器の吸振作用の良好なることは往来の摩撜制振 器の比ではない。

2. 不変速度型のばね型吸掠器は、摩撜の作用が少いのて 正規速度に於ては極めてよく作用する。

3. 振子型や波動型等の可变速度型吸振器法、吸振器を取 付けたために他に新しい共振点を生することがないので可棸 速度を要求される軸の場合に好都合である。

4. 完全な堅軸の場合でない限り、1 次の覺乱モーメント を可变速庭型動吸振器で吸收することは不可能である。

5. 振子型に対して略完全な計算が出来るから実用上便利 である。併し実驗の結果より知られる如く、振子型の㛫合に も細か心調整は実驗的に行ふことが必要である。

6. 波動型に対しては近似計算が出来るのみであり、徉て それを應用する際には計算による第 15 節 $c$ に逨へたた方法で 大体のことを定め、細か心調整は实驗に依て行ふ必要がある。

7. 振子型の場合にしても波動型の場合にしても吸振作用 の最良な $\nu_{0}{ }^{2}$ の值（即ち振幅 $A_{0}{ }^{\prime}$ の極小値を與へる $\nu_{0}{ }^{2}$ の 値)は一般に 2 箇あり、その何れを用ひてもよい訳でむるが、 併し何れかと云へば大なる力の $\nu_{0}^{2}$ の值を用ひるのがよい。

8. 振子型吸振器の場合には軸が橫であるか或は堅である 
かにより大いに異なる。即ち、吸振器を横軸に應用した場合 には測定点が甚だしく散在してるるのに対し、㹂軸に應用し た場合には可なり規則的に現はれてるる。これは横軸の場合 には振子が側壁に密着してるたり離れてるたりするが、㹂軸 の場合には自重のために振子が常に側壁と密着してるらため であらう。

9. 波動型吸振器（2 矢以上の次数の）に於ては㹂軸之㭬 軸とに対して作用は不変 $\left(A_{0}^{\prime}-\nu_{0}^{2}\right.$ の曲線つ形狀が不変) で ある。

10. 波動型吸振器に作用する摩擦は液体內部の粘性脴擦の みであつてその值は小さいものであるから、波動型を應用し
た場合の軸の振幅 $A_{0}{ }^{\prime}$ は振子型の場合よりも小さい。即ち 吸振作用は振子型よりも波動型の方が甚だよいのである。

11. 波動型吸振器の吸振作用は調整された次数の振動に対 しては主として動的作用に基つくくのである。併し液体队部 の內部摩摖は小さいもの乍ら常に作用してるるから、調整さ れない次数の振動に対しても或程度の制振作用を持つてるな。

最後に、本研究の実施に當り御指導御鞭㨒を賜はつた內丸、 丹狗、竹村、野口、䈴重の諸先生に御礼を中上げ、叉研究補 助金を交付せられた近藤記念海事財團に対し謝意を袁する。

(昭和 16 年 6 月 24 日受付)

\section{鋳鉄厚肉回壔を 3 次元問題とせる場合の近似解法 ${ }^{(1)}$}

(昭和 14 年 9 月 22 日 宗都地力蓝演會に於て講演)

正員 覚 前 睦 夫 ${ }^{(2)}$

本論文は日本機栈学會哂第 44 笔第 293 号 584 頁 (昭和 16 年 8 月) に揭載せっ論交要報を以て本交に代へる。

(1) Ein Näherungsverfahren zur Lösung des djckwandigen gusseisernen $Z y l i n d e r s$ als dreidimensionales Problem 